\title{
Contemporary Ijtihād, Ethics and Modernity
}

The practice of independent legal reasoning (ijtiha $\bar{a} d)$ is a core tool for achieving the moral mission of the discipline of Islamic jurisprudence ( fiqh); it generates juristic rulings that help people become morally committed humans. Without ijtihād, it would be inconceivable that Islamic divine law could achieve its moral mission in every time and every place. Modern scholarship has not fully explored the link between ijtihād and ethics. Most academic studies focused on the purported "closing" of the gate of ijiha $\bar{d}$, as demonstrated in the writings of many Western scholars (Schacht 1982, 69-75; Coulson 1978, 8o; Hallaq 1984, 3-41; Ali-Karamali and Dunne 1994, 238-257). Muslim scholars who wrote critical works on $\ddot{j}$ tiha $\bar{a}$ were occupied with questions related to the heritage of school-based figh and to what extent contemporary scholars should abide by, or move beyond, this heritage, and how ijtihād could be implemented in modern times (al-Nimr 1987, 105-111; al-Zarqā 1989, 147-162; al-Qaraḍāwī 1996, 101-108; 'Ațiyya 2000, 31-49; Bin Bayya 2011, 89-127). In this thematic issue, we emphasize the link between ijtihād and ethics. All articles included in this issue address key ethical questions, many of which are the product of the age of modernity.

Modern deliberations on the concept of ijtihād and those who are supposed to practice it, i.e., the mujtahidūn, have gone through various phases of development. In 1313/1896, a group of Salafī reformists in Damascus were criticized and even attacked by traditional Ottoman scholars affiliated with the Hanafì school. The main accusation was that this group of scholars was trying to practice ijtihād and thus the incident was historically known as the "Mujtahidūn Affair" (al-Qāsimī 1965, 43-69). The Ottoman tanż̄imāt (1839-1876), whose aim was to initiate the process of modernization to stop the decline of the Ottoman Empire, triggered a lengthy debate within Muslim circles about ijtihād. These deliberations on ijtihād continued among reformists in Egypt, Syria and Tunisia beginning at the end of the nineteenth century and then intensified in the second half of the twentieth century. Many texts appeared on the definition, conditions, necessities and applications of $\ddot{j} t i h \bar{a} d$, and the qualifications of the mujtahidūn, 
besides many other related issues. Many people with different educational backgrounds, specializations and convictions have engaged in the debate on ijtihād, and thus had various methods, motives and objectives in this regard.

Historically speaking, the school-based juristic tradition preserved its presence and authority throughout the centuries, and was able to accommodate new developments and novel issues by employing the mechanisms of the school (madhhab) itself. However, since the end of the nineteenth century, the pre-modern techniques of the schools were unable to address modern developments and to absorb the breathtaking changes. Rather than the single-school approach, preference was given to the so-called cross-school or trans-school approach (talfiq) wherein the jurists would select what was suitable from the vast juristic heritage produced by various schools. For instance, this trans-school approach, motivated by public interest, was adopted in personal status legislation of several states, including Syria, Tunisia and Iraq in the mid-twentieth century.

In light of these developments, the movement of Islamic reformism advocated the necessity of practicing ijtihād and abandoning uncritical imitation (taqlid), hence the emergence of several fatwas on new issues by prominent scholars like Muḥammad 'Abduh (d. 1905), Rashīd Riḍā (d. 1935), Mușțafā alMarāghī (d. 1945), 'Abd al-Wahhāb Khallāf (d. 1956), Maḥmūd Shaltūt (d. 1963), Muḥammad Abū Zahra (d. 1974), 'Abd al-Raḥmān Tāj (d. 1975) and 'Alī al-Khafîf (d. 1978). There was a surge of fatwās, premised on the cross-school approach, issued by individual scholars in the subsequent decades ('Ațiyya 2000, $36-38$ ).

Further complex developments have shown that the conventional individual approach to ijtihād (al-ijtihād al-fardī ) was no longer adequate. For instance, following the birth of the first child born through Assisted Reproductive Technology in 1978, a group of Muslim scholars started to collaborate with biomedical scientists in order to grasp new challenges. This gave rise to the mechanism of "collective ijtihād" and a number of councils have been established since the 1970s which institutionalized this mechanism. The most prominent of these are the Islamic Fiqh Council in Mecca, established in 1977, the International Islamic Fiqh Academy, established in Jedda in 1984, and the Islamic Organization for Medical Sciences, founded in 1984.

In the premodern era, tackling unprecedented issues was done through practicing ijtihād in two main ways, namely searching for an existing case that would be analogous to the unprecedented problem at hand, usually called takhrïj or qiyass 'alā al-furü', or searching for a somehow relevant scriptural reference and then interpreting it in accordance with the principles established by one of the leading figures (imäms) in one's school. However, some contemporary jurists are confused by modern radical changes, which is why 
some adopt a no-side position (tawaqquf) when they cannot determine a clear conclusion.

Against this background, contemporary ijtihād means departure from the long-established "tradition" and its hierarchy. Additionally, it also means detachment from the authority of the juristic school itself whose pre-modern parameters could not embrace these modern major changes.

This thematic issue originated from the seminar, 'Ijtihād in Contemporary Context: Concept, Functions and Methods', organized by the Research Center for Islamic Legislation and Ethics (CILE) on 27-29 September 2016 in Doha, Qatar. The seminar addressed two main questions: 1) What are the boundaries of the scope of $\ddot{j}$ tiha $\bar{a}$ (e.g., is it only restricted to juristic issues or also applicable to theological and philosophical issues?) and what are its key functions? 2) What is the most adequate methodology of $i j t i h \bar{a} d$ in the age of modernity in which both theoretical knowledge and practical reality are characterized by a high level of complexity and multidimensionality? The topic of the seminar proved to be quite appealing for researchers who seemed to be keen to practice ijtihād on the very concept of $\ddot{j} t i h \bar{a} d$. However, a great number of the original three hundred submissions did not find their way to final publication. There are eight articles included in this thematic issue, some of which were not presented at the seminar.

The articles included in this issue explore two main aspects related to the field of ethics, namely methodological themes (maqāssid, 'urf, ta'șill, ethical approach) and applied cases and concepts (human rights, changing the creation, gender equality). The eight articles are written in Arabic and English, and thus reflect the multilingual character of this journal.

\subsection{Methodological Issues}

In "Al-ḥadātha wa-tahawwulāt al-khițāb al-maqāṣidī: naḥwa figh sāil? (Modernity and the Transformations of the Maqāssidī Discourse: Towards a Liquid Islamic Law?)," Muhammad Almarakeby argues that modernity has had a great impact on the contemporary discourse on maqāṣid by giving maqāṣid a salient feature of modernity, namely liquidity. This liquidity can threaten the paradigmatic structure of Islamic jurisprudence, and circumscribe its social disciplining. Although new maqāṣidìs have different strands of thought, the majority share two characteristics: First, the inclination towards the 
rationalization of Sharīa; second, increasing the number of maqāșids and reinterpreting their meanings. The article shows how this reinterpretation turned maqāṣid into a pot in which Sharîa is merged with the subjectivities of the jurists who are influenced by their ideological, social, and political inclinations.

In "Custom and Modern Constructions of Sharīa: Transnational Juristic Discussions on the Status of 'Urf," Ayman Shabana examines modern juristic discussions on the concept of custom and shows the extent to which these discussions do not only address the role of custom in the derivation of Islamic jurisprudence, but also reflect the impact of modern positive legislations on modern conceptualizations of Sharîa and how it has been constructed in the wake of the modern legal reform movement. The framing of custom in some civil codes marked a significant development and created tension between Shari $a$ and modern legal codes. This perceived tension has inspired efforts to reaffirm the primacy of Sharîa and demands for its implementation. These discussions demonstrate how Muslim scholars situate Sharîa within national legal structures, and, at the same time, the role of juristic councils in the development of a transnational juristic discourse that transcends the boundaries of the nation state.

In "Al-ta’șil al-fighī fì al-ijtihād al-hadìth: tațwī al-figh li-muqtadayāt al-'așr (Returning to the Principles of Jurisprudence in Modern Ijtihäd: Bringing Figh into Line with Contemporary Requirements)," Abdulrahman Alhaj addresses a new reasoning method called "tașill" (returning to the roots, or governing principles) which was established by contemporary jurists to find new juristic rulings for the formidable developments of their time when they were challenged by the changing position of Sharita in the modern nation state. This new method enabled them to practice $i j t i h \bar{a} d$ by switching between different juristic schools (madhhabs), whereas before they were confined to following only one. In doing so, they confirm the validity of Sharia in modern times as well as its compatibility with the contemporary requirements, which contributes to restoring it to its former position within the state. Alhaj explains this new mechanism of reasoning and the jurisprudence based on it through examples related to the domains of politics and economics; two domains that were influenced considerably by this new method, while at the same time they reveal the nature of this jurisprudential practice that led modern jurists to break the logic of the regulatory system of Islamic jurisprudence and to adapt it to the requirements of the present reality.

In "Min al-muqāraba al-fiqhiyya ilā al-muqāraba al-akhlāqiyya: al-ijtihād al-mu'āṣir wa-l-jīnum namūdhajan (From a Fiqhī Approach to an Ethical Approach: Contemporary Ijtihäd and the Genome as a Case Study)," Mutaz 
al-Khatib argues that the fiqh-based $i j t i h \bar{a} d$ alone is no longer adequate to assess modern developments, and that there exists a dire need to move from a juristic towards an ethical approach in emerging issues. After a critical analysis of some fatwās on genomics, al-Khatib proposes a particular methodology for approaching the question of genome, which addresses two questions: What is a good and ethically justified practice? How do we know or define it? $\mathrm{Al}$-Khatib proposes his approach based on an interdisciplinary methodology that integrates philosophy, theology, and legal theory. The proposed approach is meant to improve the modes of ethical reasoning so that they will be able to cope with modern developments and their complexities. This new approach will be helpful in gaining a better understanding of the difference between figh and ethics.

\subsection{Applied Cases}

In "Al-muftì wa-l-tahdìth: al-tiqniyyāt al-țibbiyya al-hadìtha wa-atharuhā 'alā marjiciyyat al-sharīa (The Muftī and Modernization: Modern Medical Techniques and their Impact on the Position of the Sharīa)," Fatima Hafez argues that sticking to the traditional figh $\bar{\imath}$ structure will make it impossible for the Shari $a$ to continue to function as the frame of reference in the judicial system of the modern nation state. She discusses how muftis and reformist intellectuals have dealt with policies of modernization by examining the relationship between jurists and modern medical developments. These medical developments were imposed by the state without any public engagement or consultation with scholars of Islamic jurisprudence. This article explores this relationship through the examination of three main topics. First, the jurists' attitudes towards medical developments related to the field of anatomy, quarantine and vaccination. Second, the consequences of integrating modern medical techniques into the judiciary and their impact on the traditional fiqhi discourse. Third, an overview of the ijtihäd of reformists on medical issues and its impact on the official religious establishment. The article also addresses the problems that modern medical developments have given rise to in relation to the evidentiary rules adopted by Sharita courts. This system seemed to be in need of fundamental reform in order to be able to achieve the level of justice that was required by contemporary norms.

In 'Taghyīr al-khalq' wa-ahkām al-tașarruf bi-l-badan: dirāsa naqdiyya fi aqwāl al-mufassirin wa-l-fuqahä' (The Concept of 'Changing the Creation' and the Rulings on Interventions in the Body: a Critical Study of the Opinions of Exegetes and Jurists)," Abdulrahman Helli critically analyzes the concept "taghyïr al-khalq" (changing God's creation) as it became a point of reference 
in contemporary juristic discussions and fatwās on medical interventions in the human body. Helli addresses questions like: What does this concept mean? Can this concept, with its scriptural basis, be used as evidence to prohibit certain medical interventions in one's body? How was this concept understood by both Qur'ān exegetes (mufassirūn) and jurists? This article tackles these questions by consulting historical sources that deal with this concept. The author concludes by stating that the concept "taghyir al-khalq" on itself cannot be used as evidence to prohibit medical interventions in the body.

In "Islamic Human Rights and Hermeneutics of Continuity," Arnold Yasin Mol analyzes discussions on Islam and the human rights discourse and the question of their (in)compatibility. He differentiates between two forms of discourse: Islamic human rights discourse as an internal Muslim discourse and the external 'Islam and human rights' discourse which emerged together with modern human rights regimes. By analyzing the different elements of what constitutes the Islam and human rights discourse, the author suggests new understandings and strategies for creating a modern Islamic human rights discourse. This Islamic discipline of human rights provides a hermeneutics of continuity between Islam and modern human rights and overcomes both apologetics and othering.

In "Gender Equality in the Inheritance Debate in Tunisia and the Formation of Non-Authoritarian Reasoning," Sari Hanafi and Azzam Tomeh discuss the debate on gender equality in inheritance in Tunisia. This article addresses a specific type of ijtihād, which can fall within the classical term of $i j t i h \bar{a} d$ al-mukallafün, but it assumed new forms in modern times within the context of the nation state. Ijtiha $\bar{d}$, which used to be an elite intellectual activity that required strict conditions and qualifications, turned into public discussions and individual choices. This article presents an overview of the debate in Tunisia and shows the existence of three sets of arguments: jurisprudential/textual, sociological, and legal. Proponents of gender equality in inheritance base their arguments primarily on legal, then sociological, then textual grounds; by comparison, opponents base their arguments on textual, then legal, then sociological grounds. The weakness of the sociological arguments of the opponents to the law is evident when stating that a gendered division of labor within the family still exists without providing statistics or empirical evidence to back up that claim.

Besides the above-mentioned eight articles, this issue also includes two reviews of works with relevance to ijtihād and modernity. The first piece, written by Amr Osman, reviews the work of Leonard Wood, Islamic Legal Revival: Reception of European Law and Transformations in Islamic Legal Thought in 
Egypt, 1875-1952. The second review is written by Mohammed Gamal Abdelnour who presents his reading of Wael. B. Hallaq's Reforming Modernity: Ethics and the New Human in the Philosophy of Abdurrahman Taha.

\author{
Mutaz al-Khatib \\ Assistant professor of methodology and ethics at the Faculty of Islamic \\ Studies and the Center for Islamic Legislation and Ethics (CILE), Hamad Bin \\ Khalifa University \\ malkhatib@hbku.edu.qa
}

\title{
Bibliography
}

Ali-Karamali, P. Shaista and Fiona Dunne. 1994. "The Ijtihad Controversy," Arab Law Quarterly 9(3): 238-257.

Al-Nimr, 'Abd al-Mun'im. 1987. Al-ijtihād. Cairo: al-Hay’a al-Mișriyya al-Āmma li-l-Kitāb.

Al-Qaraḍāwī, Yūsuf. 1996. Al-Ijtihād fì al-Sharīa al-Islāmiyya. Kuwait: Dār al-Qalam. Al-Qāsimī, Zāâfir. 1965.Jamāl al-Dìn al-Qāsimī wa-Așruh. Damascus: Maktabat Aṭlas.

Al-Zarqā, Mușțafā. 1989. "Al-Ijtihād wa-Dawruhu fì Ḥall al-Mushkilāt." Majallat alJämía al-Islämiyya 22: 147-162.

Bin Bayya, 'Abdullāh. 2011. "Al-Ijtihād bi-Tahqīq al-Manāṭ: Fiqh al-Wāqi' wa-lMutawaqqa." Majallat al-Muslim al-Mu'āṣir, 141-142: 89-127.

Coulson, Noel J. 1978. A History of Islamic Law. Edinburgh: Edinburgh University Press.

Hallaq, Wael B. 1984. "Was the Gate of Ijtihad Closed?" International Journal of Middle East Studies 16(1): 3-41.

'Aṭiyya, Jamāl al-Dīn. 200o. "Tajdīd al-Fikr al-Ijtihādī." Majallat al-Muslim al-Mu’ạṣir, 96: 31-49.

Schacht, Joseph. 1982. An Introduction to Islamic Law. Oxford: Clarendon Press. 